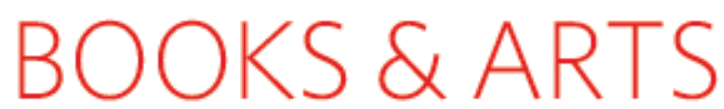

\title{
In our own hands
}

\section{Biotechnology is changing the world, but why do nations respond so differently?}

Designs on Nature: Science and Democracy in Europe and the United States

by Sheila Jasanoff

Princeton University Press: 2005. 344pp.

$\$ 35, £ 22.95$

\section{Mark Cantley}

Biotechnology, like that valuable animal the scapegoat, is a beast destined, or chosen, to bear many burdens. But is this fate deserved? The perception - widespread in Europe that biotechnology is something fundamentally new, like the discovery of electricity, or akin to black magic, is unfortunate. It has led to the assumption that there are technologyspecific risks requiring $a d$ hoc regulations and associated bureaucracies, and to consequent conflicts with sectoral regulations, as well as to international trade disputes. But not for the first time, perceptions, laws and the course of societal development may be driven by delusion. It was, after all, the scientists themselves who in 1974 proposed and accepted a moratorium on certain experiments, and the following year held the widely publicized international conference at Asilomar in California to discuss the conjectural risks of recombinant DNA.

Sheila Jasanoffhas written a carefully structured, ambitious and timely book, Designs on Nature, about the evolution of public policy on biotechnology over the past three decades in the United States, Germany, Britain and the European Union (EU), and uses this as a basis for broader conclusions. Her central idea is correct: policy arguments about biotechnology have been hijacked to serve other agendas. Opponents of multinational corporations, of the industrialization of agriculture, of US policy and of globalization have found common cause with environment ministries that seek to enlarge their powers, and with non-governmental organizations that translate GMO as 'Greenpeace membership opportunity': they all have reasons to demonize biotechnology.

Scientists invited to public or governmentsponsored forums on biotechnology soon found that the skills they needed were more akin to mud-wrestling; their expertise and experience were considered disqualifications. As in her earlier work, Jasanoff disputes that the supposedly neutral, objective, value-free process called science can be separated from the social and political matrices in which it is embedded. Rather, she emphasizes "the

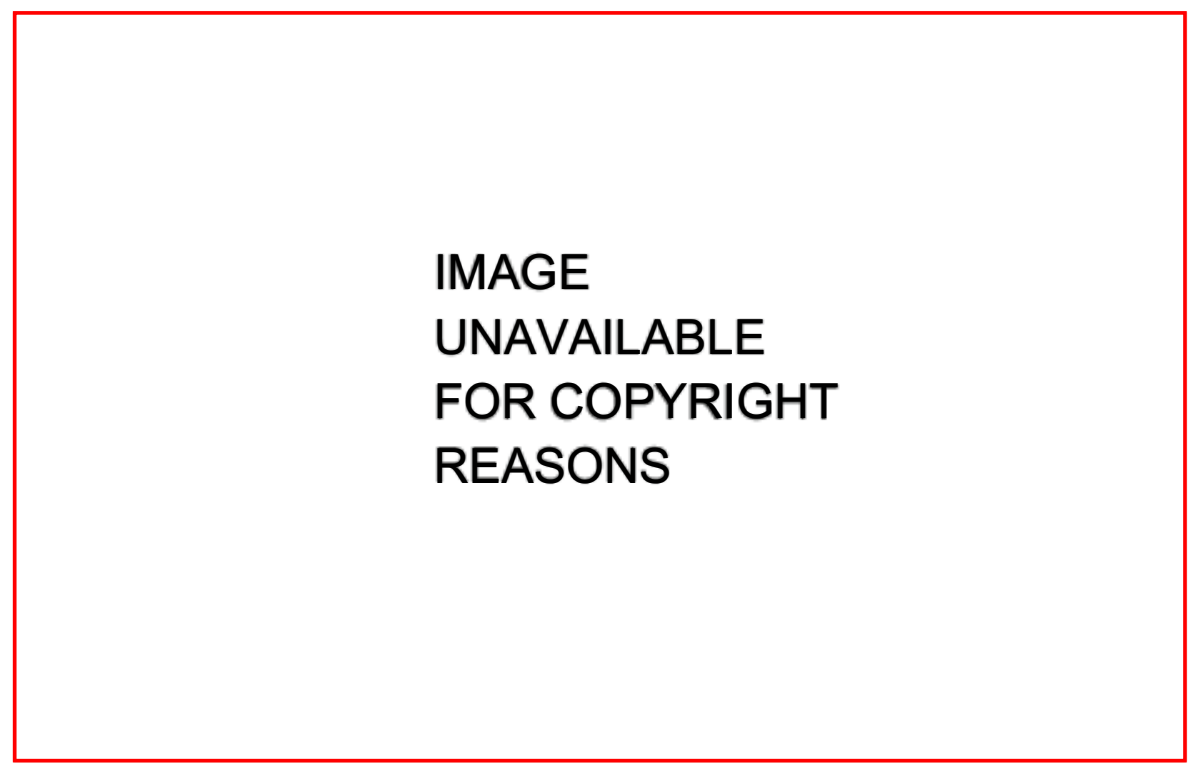

Hostile reception: some people have demonized biotechnology, particularly genetic modification.

constructed and value-laden character of scientific knowledge", and asks whether science will lose its ability to serve either state or society as a source of impartial critical authority.

Jasanoff has read widely, has broad awareness and has spoken to many people in the countries she discusses. She marshals her information carefully, using a comparative approach to illustrate how similar challenges to public policy-makers in these countries were handled differently, in ways that reflect long-standing differences in their political cultures. She focuses on "civic epistemology, the institutionalized practices by which members of a given society test and deploy knowledge claims used as a basis for making collective choices".

The book has weaknesses, however. The author, a lawyer and policy analyst rather than a scientist or historian, makes numerous errors, not all of them minor. Crick and Watson were not working at Cambridge University, and their Nobel was not for "cracking the genetic code. ${ }^{x}$ Legislation such as the EU directive on biotechnology patents, which Jasanoff discusses at length, was adopted by co-decision of the European Parliament and the Council of Ministers - not the European Commission, whose constitutional position in such legislation is restricted to drafting the proposals.

Jasanoff's use of historical evidence appears selective, and some of the omissions are eloquent counter-testimony to her thesis. Asser- tions about the separateness of the regulatory debates in the three countries (and the $\mathrm{EU}$ ) are contradicted by several years of expert debate at the Organisation for Economic Co-operation and Development (OECD), which culminated in the much-cited report Recombinant DNA Safety Considerations (OECD, Paris, 1986) and unanimous Council Recommendation recognizing "that there is no scientific basis for specific legislation to regulate the use of recombinant DNA organisms". In the late 1970 s and early 1980 s, there was close bilateral dialogue between key players in the US administration and the European Commission, with direct consequences for the 1982 Council Recommendation on recombinant DNA. Similarly, she discusses the concept of "substantial equivalence" in the context of genetically modified food regulation, but again without reference to the OECD debate and report Safety Evaluation of Foods derived by Modern Biotechnology (OECD, Paris, 1993), which popularized the use of this concept.

The author's perspective on societal learning processes fails to acknowledge their dynamic character. She notes that "as biotechnology inexorably moved from the cloistered scientific laboratory to the competitive marketplace, it became dear that the post-Asilomar settlement could not continue unamended". Yet she describes as an "about-face" what others might say were rational responses to the 
progress of knowledge and the accumulation of experience.

One might dispute Jasanoff's assertion that there "was no storehouse of precedents that policymakers could reach into for historically documented evidence concerning the widespread use of laboratory-crafted organisms". Modern biotechnology brings precision, but no fundamental change, to the long-standing practices of selective breeding and random mutagenesis, which had been used in the fermentation and seed industries for many decades before the debates on recombinant DNA.

Jasanoff's thesis rests on stronger ground when she turns to the ethical impacts of modern biotechnology and genomics, and the differing national responses, which she discusses and compares in detail: "Genetic engineering transgresses some of the most deeply entrenched categories of western thought... Designs on nature - once thought to be the prerogative only of a divine creator - seem now well within the reach of human capability," she writes. The "controlling narratives" that framed the course of policy development include not only a novel process for intervening in nature, and a source of new products, but " a state-sponsored program of standardization and control carrying profound implications for human dignity and freedom, and raising questions of constitutional significance. . Given the profundity of the challenges thus brought into public and policy debates, democratic theory in the era of the knowledge society must take on board the involvement of citizens in the production, use and interpretation of knowledge for public purposes.

She offers three main conclusions. First, that core concepts of democracy such as citizenship and accountability cannot be satisfactorily understood without considering the politics of science and technology. Second, that in all three countries (and the EU), policies for the life sciences have been incorporated into 'nation-building' projects that seek to reimagine what the nation (or Europe) stands for. Third, that political culture matters to democratic culture, and works through the institutionalized ways in which citizens understand and evaluate public knowledge. These three aspects of contemporary politics help account not only for policy divergences between nations, but also for the perceived legitimacy of state actions.

These conclusions are well supported, and useful not least for indicating why scientific, industrial or other communities have found it difficult to influence policy. So the book succeeds in its aims. The policy debates have served to crystallize the emergence of a European polity and self-awareness. But the reader is left wondering: what if these high policy debates are founded on misperceptions, which they reinforce?

Mark Cantley is adviser, Research Directorate-

General of the European Commission, on

Biotechnology, Agriculture and Food.

\section{A scientist's life in Russia}

\section{About Science, Myself and Others \\ by V. L. Ginzburg, \\ Institute of Physics/Taylor \& Francis: 2004. \\ 549 pp. $\$ 99.95$}

\section{Alan L. Mackay}

Vitali Ginzburg, winner of the 2003 Nobel Prize for physics, was born in Moscow in 1916. He has survived, through intellect, character and chance, through the whole tempestuous and tragic period of the Soviet Union. He experienced two world wars, a revolution, leninism, stalinism, the fall of the Soviet Union, and the chaotic present-day reconstruction of Russia at the hands of 'gangster capitalism.'

About Science, Myself and Others deals with some immense topics: the circumstances of the Soviet Union, the history of branches of fundamental physics, and the lives of distinguished physicists, especially Lev Landau. In particular, Ginzburg focuses on struggles in three main areas: fundamental physics, the mechanics of daily life, and the ideologies of politics and religion.

Since the rise of Mikhail Gorbachevin 1985, Ginzburg has produced various accounts of his life and work, biographical sketches of his contemporaries, and more general pieces. About Science, Myself and Others is an English translation of the latest Russian edition, from 2003, which brought together scattered material but with some repetition and no index. It also contains material based on chapters published in his earlier book The Physics of $a$ Lifetime (Springer, 2001), and includes its contents list. The new collection contains a mass of detailed information on physics and on people, making it indispensable, particularly to those interested in the school of Landau and his fellow Nobel laureate Igor Tamm.

Ginzburg writes his apologia pro vita sua not as an apology but with a (justified) ${ }^{\alpha}$ fair conceit of himself" for posterity as his "version of the facts". He makes little concession to the ignorant and suggests a simple test of general knowledge for politicians and others. For example: "Q. What causes the seasons? A. The inclination of the axis of the Earth to the plane of its orbit." He writes that he has found interviews unsatisfactory, and in one paper he even wrote both the questions and his answers.

Most people have sought " to render unto Caesar what is Caesar's and to God what is God's", with a boundary between their inner beliefs and the society in which they live. But Ginzburg has always had an intense concern not just for physics but for the welfare of Russia. In 1989, during the Gorbachev era, he even became a deputy in the Supreme Soviet (the parliament), representing the Soviet Academy of Sciences, but left politics in 1991. In recent years he has been "an incorrigible
IMAGE UNAVAILABLE FOR COPYRIGHT REASONS

Vitali Ginzburg looks back on the science that flourished amid the political turbulence in Russia.

atheist", and campaigned against the revival of the Orthodox Church and pseudoscience of all kinds.

Ginzburg never suffered personal repression from the authorities, and in fact was honoured by the state, primarily for his work on the nuclear-weapons programme. He made a key contribution to the physics of the hydrogen bomb, proposing the use of lithium-6 deuteride as a nuclear source - a suggestion that surprised the Americans and brought him, in late 1953, the Order of Lenin and the Stalin prize first class. $\mathrm{He}$ might otherwise have suffered repression from the state following his marriage to Nina Ermakova, who had been exiled to Gorki and whose father was falsely regarded as an enemy of the state.

If history is a line with branch points at arbitrary decisions, then the whole manifold of all possible trajectories might be viewed as a tree. If this is the history of Russia, what shape is this tree of all possible paths? How different could it have been? The science theoretician Arnosht Kolman entitled his autobiography of disillusionment Our Lives Should Have Been Different (1982). How would Nikolai Bukharin, for example, have dealt with the situation if he, instead of Stalin, had succeeded Lenin?

Karl Marx hoped to discover laws and regularities in human history, as did the 'general systems' movement from Bertalanffy to Peter Turchin today, but the practical results have been slight. Ginzburg points to the key branch point: "I believe that the fundamental and principal cause of all these disasters is the Bolshevist-Communist totalitarian regime which was set up in Russia as a result of the coup détat in October 1917," which followed the February 1917 revolution that deposed the tsar.

The first part of the book is a detailed review of the physics that concerned Ginzburg, including radiation from uniformly moving sources (the Vavilov-Cherenkov effect), cosmic rays, soft modes, superconductivity and superfluidity. It manages to place his own 